\title{
Resistance to Cucurbit aphid-borne yellows virus in Melon Accession TGR-1551
}

\author{
Mona A. Kassem, Blanca Gosalvez, Elisa Garzo, Alberto Fereres, Maria Luisa Gómez-Guillamón, and Miguel A. Aranda \\ First, second, and sixth authors: Centro de Edafología y Biología Aplicada del Segura (CEBAS), Consejo Superior de Investigaciones Científicas \\ (CSIC), P.O. Box 164, 30100 Espinardo, Murcia, Spain; third and fourth authors: Instituto de Ciencias Agrarias (ICA), CSIC, Serrano 115 \\ dpdo, 28006, Madrid, Spain; and fifth author: Instituto de Hortofruticultura Subtropical y Mediterránea "La Mayora", Universidad de Málaga- \\ Consejo Superior de Investigaciones Científicas (IHSM-UMA-CSIC), 29750 Algarrobo-Costa, Málaga, Spain.
}

Accepted for publication 4 June 2015.

\begin{abstract}
Kassem, M. A., Gosalvez, B., Garzo, E., Fereres, A., Gómez-Guillamón, M. L., and Aranda, M. A. 2015. Resistance to Cucurbit aphid-borne yellows virus in melon accession TGR-1551. Phytopathology 105:1389-1396.

The genetic control of resistance to Cucurbit aphid-borne yellows virus (CABYV; genus Polerovirus, family Luteoviridae) in the TGR-1551 melon accession was studied through agroinoculation of a genetic family obtained from the cross between this accession and the susceptible Spanish cultivar 'Bola de Oro'. Segregation analyses were consistent with the hypothesis that one dominant gene and at least two more modifier genes confer resistance; one of these additional genes is likely present in the susceptible parent 'Bola de Oro'. Local and systemic accumulation of the virus was

compared with susceptible controls, but not locally in agroinoculated cotyledons. In aphid transmission experiments, CABYV inoculation by aphids was significantly reduced in TGR-1551 plants, although the virus was acquired at a similar rate from TGR-1551 as from susceptible plants. Results of feeding behavior studies using the DC electrical penetration graph technique suggested that viruliferous aphids can salivate and feed from the phloem of TGR-1551 plants and that the observed reduction in virus transmission efficiency is not related to reduced salivation by Aphis gossypii in phloem sieve elements. Since the virus is able to accumulate to normal levels in agroinoculated tissues, our results suggest that resistance of TGR1551 plants to CABYV is related to impairment of virus movement or translocation after it reaches the phloem sieve elements.
\end{abstract} analyzed in a time course experiment, showing that TGR-1551 resistance was expressed systemically as a significant reduction of virus accumulation
Additional keywords: Cucumis melo, luteovirus.
Cucurbit aphid-borne yellows virus (CABYV) is a member of the genus Polerovirus within the family Luteoviridae. CABYV was first described in 1992 in France (Lecoq et al. 1992), but it was later detected infecting cucurbits in many other countries (Bananej et al. 2009; Kassem et al. 2007; Knierim et al. 2010; Lecoq et al. 1992; Lemaire et al. 1993; Yardimci and Özgönen 2007). Extensive surveys conducted by $\mathrm{H}$. Lecoq and coworkers showed that CABYV is one of the most common cucurbit viruses found in open field cucurbit crops in a great diversity of areas and environments (Lecoq 1999; Lecoq et al. 2003). CABYV is by far the prevalent virus in cucurbit crops in Southeastern Spain, with incidences in more than $20 \%$ of the plants in over $70 \%$ of the plots included in an extensive survey (Juárez et al. 2004, 2013; Kassem et al. 2007). CABYV is a phloem-limited virus that is transmitted in a persistent, nonpropagative manner by aphids such as Aphis gossypii and Myzus persicae (Lecoq et al. 1992). Typical symptoms of CABYV infection include yellowing and thickening of basal and older leaves, and can lead to flower abortion. In the case of melon and cucumber, a high percentage of flower abortion was detected, although fruit quality was not affected (Lecoq et al. 1992). CABYV particles are isometric, about $25 \mathrm{~nm}$ diameter, and encapsidate the CABYV genome, which consists of a single-stranded, positive-sense RNA molecule that is 5.7 $\mathrm{kb}$ in length (D'Arcy and Domier 2005). The CABYV genome contains at least six open reading frames (ORFs) organized into two clusters (Ashoub et al. 1998; Mayo and Ziegler-Graff 1996; Kassem et al. 2013), which code for the silencing suppression, RNAdependent RNA polymerase, aphid transmission, particle packaging,

Corresponding author: M. A. Aranda; E-mail address: m.aranda@cebas.csic.es and virus movement functions (Boissinot et al. 2014; Brault et al. 1995, 2005; Gildow et al. 2000; Guilley et al. 1994; Pfeffer et al. 2002, 2006; Ziegler-Graff et al. 1996).

Control of CABYV is essentially based on chemical control of its aphid vectors, with the corresponding potential damage to the environment and risk of selection of resistant aphid populations. The use of physical barriers against the aphids, such as plastic covers during the early stages of plant development, seems to be associated with a delay in the establishment of infections of a few weeks, but does not confer permanent or efficient protection (Lecoq 1999). Under these circumstances, the use of cultivars that carry genetic resistance to the virus is the best option for disease control (Gómez et al. 2009). In melon, accession PI 124112 shows resistance to CABYV, which is controlled by two complementary recessive genes (Dogimont et al. 1997). However, to our knowledge, commercial melon cultivars carrying genetic resistance to CABYV have not been released yet. Additional sources of resistance to CABYV have been identified in melon (Dogimont et al. 1996), but the genetic bases of these resistances are unknown.

TGR-1551 is a particularly interesting melon accession that carries the Vat gene, which prevents A. gossypii colonization and the subsequent transmission of nonpersistently transmitted viruses (Garzo et al. 2002; Sarria et al. 2007, 2009b, 2010; Soria et al. 2003). TGR-1551 also shows resistance to the virus vector Bemisia tabaci (Palomares-Rius et al. 2007; Soria et al. 1999). Furthermore, this melon accession shows resistance to powdery mildew (YusteLisbona et al. 2010, 2011a, b), Cucurbit yellow stunting disorder virus (CYSDV) (López-Sesé and Gómez-Guillamón 2000; Marco et al. 2003), and Watermelon mosaic virus (WMV) (Díaz-Pendón et al. 2005; Palomares-Rius et al. 2011; González-Ibeas et al. 2012). Remarkably, our preliminary analyses suggested that TGR-1551 could also be resistant to CABYV. Here, we show data validating 
this hypothesis, characterizing the mode of expression of this resistance and its mode of inheritance.

\section{MATERIALS AND METHODS}

Plant material. Field trials were conducted using Cucumis melo 'Bola de Oro' and accession TGR-1551 (C-105) (IHSM-La Mayora germplasm collection, Málaga, Spain). Evaluation of CABYV susceptibility was carried out under experimental conditions for 13 additional melon accessions, including cultivars 'Marca', 'Panal', 'Ricamiel', and "Canario" (Semillas Fitó, Spain), 16987 (Seminis, Spain), 'Primal' (Syngenta Seeds, Spain), as well as accessions BGV10122 and BGV-10130 (COMAV germplasm collection, Valencia, Spain), C-35, C-46, C-311, C-757 (IHSM-La Mayora germplasm collection, Málaga, Spain), and PI 124112 (INRA, France). Seeds used in the analysis of resistance inheritance were also obtained from IHSM-La Mayora (Málaga, Spain). These included the two parental lines (TGR-1551 and 'Bola de Oro'), their $\mathrm{F}_{1}$ and $\mathrm{F}_{2}$ generations, a first back-cross to the resistant parental line $\left(\mathrm{F}_{1} \times\right.$ TGR-1551, $\left.\mathrm{BC}_{1 \mathrm{R}}\right)$, and a first back-cross to the susceptible parental $\left(\mathrm{F}_{1} \times\right.$ 'Bola de Oro', $\mathrm{BC}_{1 \mathrm{~S}}$ ). Seeds of the resistant genotype PI 124112 and its $\mathrm{F}_{2}$ generation after crossing with TGR-1551 were also used in this study. Laboratory assays for evaluation of TGR-1551 resistance to CABYV aphid transmission was conducted using 'Primal' as susceptible control.

CABYV inoculation. CABYV was inoculated using an agroinfectious clone for all except vector transmission experiments. The clone was pBIN35SCA-WT, provided by V. Ziegler-Graff (IBMPCNRS, Strasbourg, France). Agrobacterium tumefaciens-transformed cells were grown overnight at $28^{\circ} \mathrm{C}$ in $\mathrm{LB}$ media, with rifampicin $(100 \mu \mathrm{g} / \mathrm{ml})$ and kanamycin $(50 \mu \mathrm{g} / \mathrm{ml})$ antibiotics. The following day, the volume of the culture was increased 10 times and kept in agitation at $28^{\circ} \mathrm{C}$ until optical density (O.D.) $=0.7$; at this point cells were harvested by centrifuging at $5,000 \mathrm{rpm}$ for $8 \mathrm{~min}$, and resuspended in SIM buffer $(10 \mathrm{mM}$ sodium citrate and $2 \%$ sucrose at $\mathrm{pH}$ 5.5) until reaching 0.5 O.D.; then acetosyringone (Sigma) was added up to $150 \mu \mathrm{M}$ and the suspension was kept overnight in agitation at $25^{\circ} \mathrm{C}$. Before agroinoculation, cells were collected and resuspended in SIM-acetosyringone buffer at O.D. 1. Agroinoculation was performed in the abaxial side of expanded cotyledons approximately 1 week after germination using 1-ml syringes without the needle. The CABYV isolate used for aphid transmission experiments (see below) was provided by H. Lecoq (Station de Pathologie Végétale, INRA, Montfavet, France). It was collected from an infected zucchini squash in 2003 in Montfavet, France, and maintained on melon plants ('Primal'). After inoculation, plants were kept in an insect-proof glasshouse at approximately $25^{\circ} \mathrm{C} / 18^{\circ} \mathrm{C}$ day/night.

CABYV detection and quantification. For detection of CABYV positive-sense RNA in tissue prints (Marco et al. 2003), plant petioles of the 8th and 12th leaves of 4 week posttransplanting plants were cut with a razor blade and cross-sections were blotted onto positively charged nylon membranes (Roche Diagnostics GmbH, Mannheim, Germany) immediately after cutting. CABYV RNA on membranes was detected by molecular hybridization as described in Marco et al. (2003). The CABYV probe was prepared from a plasmid as described by Kassem et al. (2007).

Total RNA was extracted from CABYV and mock-inoculated plants by using Tri Reagent (Sigma Chemical Co., St. Louis, MO). For dot-blot and real-time quantitative PCR (RT-qPCR), all leaves from each plant were homogenized in $10 \mathrm{mM}$ Tris- $\mathrm{HCl}, \mathrm{pH} 8,5 \mathrm{mM}$ EDTA, $\mathrm{pH} 8$, and $2 \%$ sodium dodecyl sulfate with a Polytron. One milliliter of the homogenate was taken and total RNA was extracted from this sample as in Gómez et al. (2009). RNA concentration and quality were determined in duplicate using a NanoDrop ND-1000 UV-vis spectrophotometer (NanoDrop Technologies, Wilmington, DE) and agarose gel electrophoresis, respectively. RNA concentrations were adjusted to $100 \mathrm{ng} / \mu \mathrm{l}$ and then stored in aliquots at $-80^{\circ} \mathrm{C}$.
For quantitative dot-blots, the amount of CABYV positive-sense RNA in samples was estimated according to hybridization signals. For each sample, $1 \mu \mathrm{l}$ of the total RNA extract and $1 \mu \mathrm{l}$ of a 1:10 dilution were spotted onto a nylon membrane. Additionally, $1 \mu \mathrm{l}$ of CABYV-transcribed RNA at a concentration of $10 \mu \mathrm{g} / \mathrm{ml}$ plus a dilution series were spotted onto the membrane. Blots were then subjected to UV RNA-cross-linking, prehybridized, hybridized, washed, and developed to detect CABYV RNA as described by Kassem et al. (2007). Membranes were exposed to X-ray films and the resulting autoradiographs were transilluminated and their images acquired by a digital camera (Bio-Rad Gel Doc EQ, Segrate, Italy). Digitized images were computer-analyzed to quantify the intensity of the signal on each dot. Dots corresponding to the samples of CABYVtranscribed RNA provided the values for calibrating the relationship between signal intensity and amount of viral RNA. This calibration served to interpolate the values for the amounts of viral RNA in the test samples. Eventually, the amount of CABYV RNA was referred to the amount of total RNA in each extract.

For northern blot detection and quantification, $1 \mu \mathrm{g}$ of denatured total RNA was electrophoresed on agarose gels containing formaldehyde. RNAs were transferred to positively charged nylon membranes (Roche Diagnostics) by blotting. After UV cross-linking, membranes were prehybridized, hybridized, washed and developed to detect CABYV RNA as described above. Autoradiographs were digitized, and images were computer-analyzed to quantify the intensity of the signal on each band. Dilutions of an in vitro transcript run in parallel provided the values for calibrating the relationship between signal intensity and amount of viral RNA, as estimated by the addition of estimates for genomic and subgenomic RNAs. Eventually, the amount of CABYV RNA was referred to the amount of total RNA in each extract.

For CABYV RNA detection and quantification by RT-qPCR, two primers (CABYV-F and CABYV-R) annealing to a partial sequence of the virus isolate and a TaqMan MGB-probe (Applied Biosystems) spanning positions 3994 to 4014 of the CABYV genome were used as described by Moreno et al. (2011). A positive RNA transcript and 10fold serial dilutions were used to generate an external standard curve (Moreno et al. 2011). Expand Reverse transcription (Roche) with $100 \mathrm{ng}$ of extracted RNA in a 20- $\mu$ l reaction was used for reverse transcription, and TaqMan Gene Expression Master Mix (Applied Biosystems) with $10 \mathrm{ng}$ of cDNA in a $25-\mu \mathrm{l}$ reaction was used for PCR. Amplification and detection was carried out using an AB7500 Real-Time PCR System (Applied Biosystems, Foster City, CA) by heating to $50^{\circ} \mathrm{C}$ for $2 \mathrm{~min}$, and then $90^{\circ} \mathrm{C}$ for $10 \mathrm{~min}$, followed by 40 cycles of $95^{\circ} \mathrm{C}$ for $15 \mathrm{~s}$ and $60^{\circ} \mathrm{C}$ for $1 \mathrm{~min}$. Each sample was analyzed using three technical replicates. Each real-time RT-PCR assay included the CABYV calibration controls, positive controls, negative controls from healthy plants, and a nontemplate control that consisted of the reaction mixtures without RNA. The standard curve, range of detection, correlation coefficient $\left(R^{2}\right)$, and the amplification efficiency (E) were determined for each assay. The mean cycle threshold $(\mathrm{Ct})$ values and standard deviations were calculated for each sample. The amplification efficiency was calculated using the following

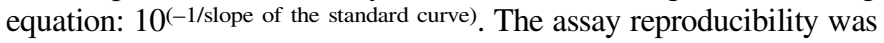
determined by testing each dilution of the RNA transcript between and within each assay. The intra-assay and interassay coefficients of variation were calculated by dividing the standard deviation of the $\mathrm{Ct}$ values of replicates by the mean $\mathrm{Ct}$ values of replicates using Microsoft Excel.

For detection of CABYV in transmission experiments, we used a polyclonal antibody ELISA kit for CABYV, provided by D. Peters (Virology Laboratory, Wageningen University, the Netherlands).

Inheritance of CABYV resistance in TGR-1551. The inheritance mode of TGR-1551 resistance to CABYV was studied in a genetic family composed of line TGR-1551 (7 plants), the susceptible 'Bola de Oro' (10 plants), and their $\mathrm{F}_{1}$ (10 plants), $\mathrm{F}_{2}$ (240 plants), $\mathrm{BC}_{1 \mathrm{R}}$ (44 plants), and $\mathrm{BC}_{1 \mathrm{~S}}$ (69 plants) offspring. Simultaneously, an allelism test was performed by the agroinoculation of 
an $\mathrm{F}_{2}$ (99 plants) obtained from the cross between TGR-1551 and PI 124112. Plants were agroinoculated as described above and, at 15 days postinoculation (dpi), viral accumulation was estimated for each plant by quantitative dot-blot hybridization (see above) and expressed as nanogram of viral RNA per microgram of total RNA; this was considered the phenotypic value of each plant. Determination of the number of loci involved in the inheritance of CABYV resistance in the TGR-1551 × 'Bola de Oro' genetic family was made upon $\chi^{2}$ testing of departure from expected resistant/susceptible ratios for different genetics models. Also, in order to estimate the genetic components of the character, data from the TGR-1551 $\times$ 'Bola de Oro' genetic family were analyzed according to Mather and Jinks (1982). Data were then transformed to $\log (x+1)$. The adequacy of additive-dominance models with and without digenic epistatic interactions was tested by the Joint Scaling tests. The evaluated models employed to estimate gene effects include additive $(d)$ and dominance $(h)$ effects, and the digenic epistatic interactions: additive $\times$ additive $(i)$, additive $\times$ dominance $(j)$, and dominance $\times$ dominance $(l)$. The genetic model showing less deviation from the expected to the observed means, according to $\chi^{2}$ test, was considered the best-fitted model. The minimum number of genetic factors and its error were estimated by the formulae of Lande (1981) modified by using the phenotypic range of the segregating populations involved (Bjarko and Line 1988) that does not take into account all the positive alleles coming from the donor parent.

Aphid transmission experiments. A virus-free laboratory colony of A. gossypii was initiated from a single virginiparous apterae adult collected from a melon crop in Almeria, Spain in 1998. Colonies (plants and aphids) were kept in a climate-controlled chamber at $25^{\circ} \mathrm{C}$ and a $16 / 8 \mathrm{~h}$ light/dark photoperiod. For the generation of CABYV-infected plants used in transmission experiments, virus-free aphid nymphs (24-h-old) were placed on pieces of CABYV-infected leaves $(3 \mathrm{~cm}$ diameter $)$ in plastic cages $(10 \times$ $7 \mathrm{~cm}$ ) for a $48 \mathrm{~h}$ acquisition access period (AAP). The nymphs were then transferred to test plants for a $72 \mathrm{~h}$ inoculation access period (IAP). Then, plants were sprayed with Confidor 20SL and placed in an aphid-free greenhouse compartment for 3 or 4 weeks at $22 \pm 2{ }^{\circ} \mathrm{C}$, about $70 \%$ relative humidity, and a $16 / 8 \mathrm{~h}$ light/dark photoperiod. To test CABYV transmission to TGR-1551 plants, two different inoculation experiments were performed. In experiment 1, the DC electrical penetration graph (EPG) technique (Tjallingii 1985) was used to monitor the probing and feeding behavior of viruliferous young apterous adult aphids ( 7 to 8 days old) during an IAP of $48 \mathrm{~h}$ on both TGR-1551 and Primal plants. The aphids, which were previously subjected to a $48 \mathrm{~h}$ AAP on CABYVinfected leaves, were connected to the EPG device (Giga-4 or Giga-8, manufactured by Wageningen University, The Netherlands) as described by Moreno et al. (2011). Aphids were placed on the abaxial side on the youngest expanded melon leaf. The recording was performed immediately after wiring the aphid at about $20^{\circ} \mathrm{C}$ and constant light in the laboratory. Data acquisition and waveform analysis were mediated by Probe 3.0 software (Wageningen University, Entomology Lab). EPG variables were processed using the EPG-Excel data Workbook, developed by Sarria et al. (2009a). The analysis of EPG patterns included waveform E1, linked to salivation in phloem sieve elements and inoculation of Barley yellow dwarf virus (BYDV) as well as waveform E2 associated to phloem sap ingestion and acquisition of BYDV (Prado and Tjallingii 1994). Single viruliferous aphids connected to the EPG device were placed first on 'Primal' plants and then transferred to TGR-1551 test plants. Thirteen single-aphid EPG recordings per treatment were used. Only EPG recordings that showed stylet activities during the full $48 \mathrm{~h}$ period were considered for analysis. The 13 test plants of each susceptible and resistant melon genotypes were used for virus detection. Direct pairwise comparisons of the variables related to feeding behavior between both plant genotypes were made by a Mann-Whitney $U$ test. A statistical test was conducted using IBM Statistics SPSS 19.0 software. In experiment
2, the transmission rate of CABYV to both 'Primal' and TGR-1551 plants by $A$. gossypii using 10 aphids per plant was compared. Ten young adult aphids were subjected to a $48 \mathrm{~h}$ AAP on 'Primal'infected plants and then transferred to either 'Primal' or TGR-1551 test plants for a $72 \mathrm{~h}$ IAP. The experiment was repeated twice using 10 to 20 test plants per each melon genotype. The transmission rate, calculated as a percentage, was compared among the different melon genotypes using a $\chi^{2}$ test and if the expected values were lower than 5, a Fisher's exact test was used (StatView 4.01 for Macintosh; Abacus Concepts, Berkeley, CA).

For CABYV acquisition experiments from TGR-1551 plants by aphids, 20 virus-free adult aphids were allowed to produce nymphs for $24 \mathrm{~h}$ on CABYV-infected TGR-1551 (as resistant) melon plants. After removing the adults, the nymphs were allowed to feed for an AAP of $48 \mathrm{~h}$ on TGR-1551 source plants. Then, nymphs were placed on test 'Primal' plants (10 nymphs/plant) for an IAP of $72 \mathrm{~h}$. Test plants were sprayed with Confidor as described above and then checked for virus infection by an ELISA test 20 days after.

\section{RESULTS}

TGR-1551 shows resistance to CABYV. Overall performance of TGR-1551 versus 'Bola de Oro' plants was compared in an open field trial. Soon after transplanting and coincident with heavy aphid infestations, severe yellowing symptoms typically induced by CABYV were observed in most 'Bola de Oro' plants, while symptoms were sporadic and mild in TGR-1551 plants. Seventy-five percent of the plants were analyzed by molecular hybridization in tissue prints of stem cross-sections at 4 weeks after transplanting to determine whether they were infected with CABYV. Results showed that most of the 'Bola de Oro' but only a small fraction of the TGR-1551 plants were infected, with the hybridization signal much more intense for "Bola de Oro" than for TGR-1551 (Fig. 1). These results suggested that TGR-1551 is resistant to CABYV, though resistance to aphids or to virus transmission in this accession could not be ruled out. To discriminate among these possibilities, TGR-1551 plants were then experimentally inoculated with CABYV using an agroinfectious clone (Prüfer et al. 1995). We included in this analysis, along with TGR-1551, six plants per accession from 15 additional melon accessions (see Materials and Methods). Accession PI 124112 (Dogimont et al. 1996) and 'Bola de Oro' were used as resistant and susceptible controls, respectively. Plants were sampled at 2 and 4 weeks postinoculation

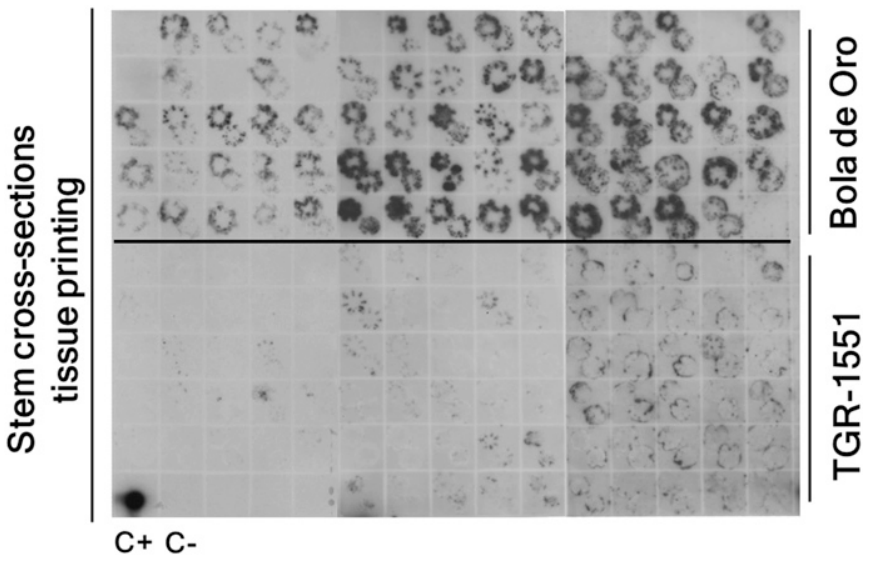

Fig. 1. Molecular hybridization in tissue prints of petiole cross-sections to determine Cucurbit aphid-borne yellows virus (CABYV) infection in 'Bola de Oro' (top panel) and TGR-1551 (bottom panel) plants in an open field trial. Sections of two petioles from each plant, corresponding to the 8th and 12th leaves, respectively, were printed into each square of the membrane. Plants were sampled 4 weeks after transplanting. Positive control $(\mathrm{C}+)$ is in vitrotranscribed, positive-sense CABYV RNA (10 ng) and negative control (C-) is total RNA (500 ng) extracted from a healthy melon plant. 
and analyzed by quantitative dot-blot molecular hybridization to estimate CABYV accumulation. The classification of the accessions in relation to their CABYV susceptibility was performed according to the level of symptom expression (visual estimation) and the intensity of the hybridization signal. Thus, accessions BGV-10130, C-311, C-757, 'Bola de Oro', 'Rochet', and 'Tendral' showed very intense dot-blot hybridization signals and evident yellowing symptoms; accessions C-35, 'Piel de Sapo', 'Amarillo', and 'Primal' showed heterogeneous inoculation responses in relation to both virus accumulation and symptom expression; accessions BGV-10122, 16987, and C-46 showed virus accumulation levels between 12 and 30\% of those of 'Bola de Oro' and inconspicuous symptoms; finally, accessions TGR-1551 and PI 124112 showed no symptoms and hybridization signals were only detectable after long exposure times and only for a small proportion (50 to $30 \%$ ) of the inoculated plants, thus confirming that TGR-1551 is resistant to CABYV.

Accumulation of CABYV in TGR-1551 plants in a time course experiment. The accumulation of viral RNA in 'Bola de Oro', TGR-1551, and PI 124112 plants agroinoculated with CABYV was analyzed in agroinoculated cotyledons at $10 \mathrm{dpi}$, and in leaves at 15,25 , and $35 \mathrm{dpi}$, using 10 plants per accession and sampling date.

CABYV RNA accumulation in inoculated cotyledons was analyzed by northern blot hybridizations, where identification of subgenomic RNAs is an unequivocal indication of virus replication. Genomic $(6.5 \mathrm{~kb})$ and subgenomic $(2.3 \mathrm{~kb})$ CABYV RNAs were detected in all samples from resistant and susceptible plants (Fig. 2), indicating that the virus infected cotyledons of all plants. Estimated values of viral RNA accumulation in cotyledons were variable within each accession, and ranged between 16 and 62 (35.10 \pm 12.45$), 20$ and $48(34.75 \pm 11.52)$, and 39 and $53(45.19 \pm 6.14) \mathrm{ng}$ of viral RNA/ $\mu \mathrm{g}$ of total RNA for TGR-1551, 'Bola de Oro', and PI 124112, respectively. More importantly, there were no statistically significant differences among averaged values (least significant difference $t$ test, $P<0.05)$, indicating that CABYV is capable of multiplying and accumulating in the agroinoculated cotyledons of resistant accessions in amounts similar to those in the susceptible control.

\section{TGR-1551 Bola de Oro PI 124122}

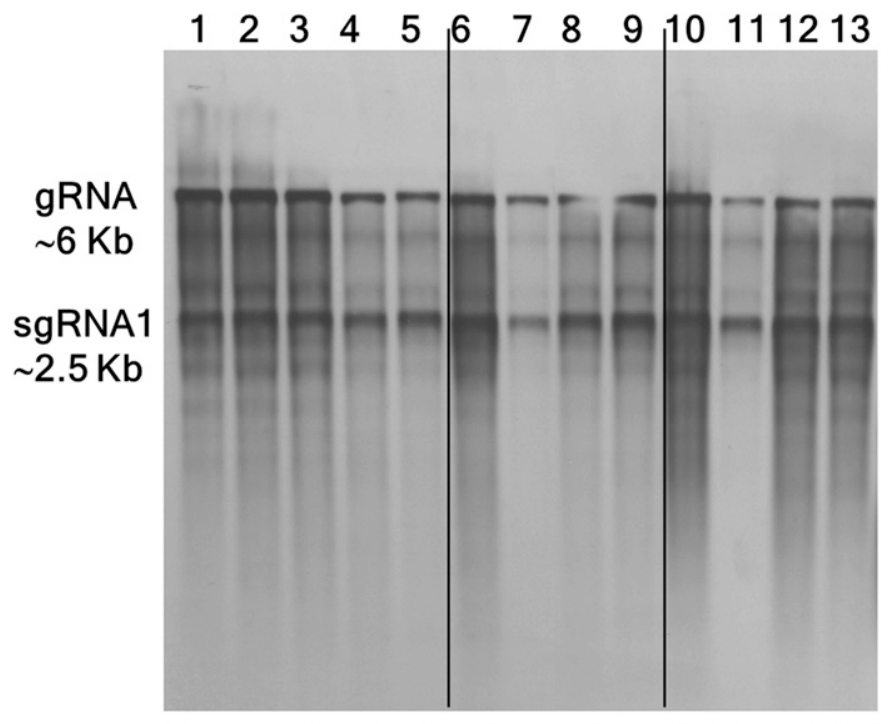

RNAr

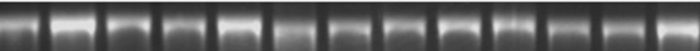

Fig. 2. Detection and quantification by northern blot hybridization of Cucurbit aphid-borne yellows virus RNA accumulation in inoculated cotyledons of three melon accessions. The genomic RNA and subgenomic RNA1 are marked on the left side of the figure. The lower panel shows ribosomal RNA as a loading control.
Sampling leaves to estimate virus accumulation may be subject to large errors due to irregular virus distribution, therefore quantification of systemic accumulation of CABYV RNA was performed by sampling homogenates of all plant leaves above the cotyledons from each tested plant at 15, 25, and 35 dpi (Fig. 3A) and quantitating virus accumulation by RT-qPCR in the samples. Resistant accessions showed significantly less CABYV RNA accumulation than the susceptible control for all time points and did not develop yellowing symptoms (Fig. 3B). Viral accumulation in 'Bola de Oro' and PI 124112 increased with time up to $35 \mathrm{dpi}$, whereas for TGR-1551, viral accumulation peaked at $25 \mathrm{dpi}$, though differences on viral RNA content were not statistically significant at 25 and 35 dpi for plants of this accession. In conclusion, both TGR1551 and PI 124112 inoculated plants showed significantly reduced accumulation of CABYV compared with susceptible control plants. Interestingly, resistance in TGR-1551 and PI 124112 expresses systemically but not locally in agroinoculated cotyledons.

Inheritance of CABYV resistance in TGR-1551. Resistance was studied based on systemic accumulation of CABYV at $15 \mathrm{dpi}$, because by this time after inoculation differences between susceptible and resistant accessions were already significant and sufficiently large (Fig. 3A). Thus, to evaluate the inheritance mode of resistance to CABYV found in TGR-1551, A. tumefaciensmediated infection of plants from a genetic family was used. In this case, accumulation of CABYV RNA in each plant was estimated

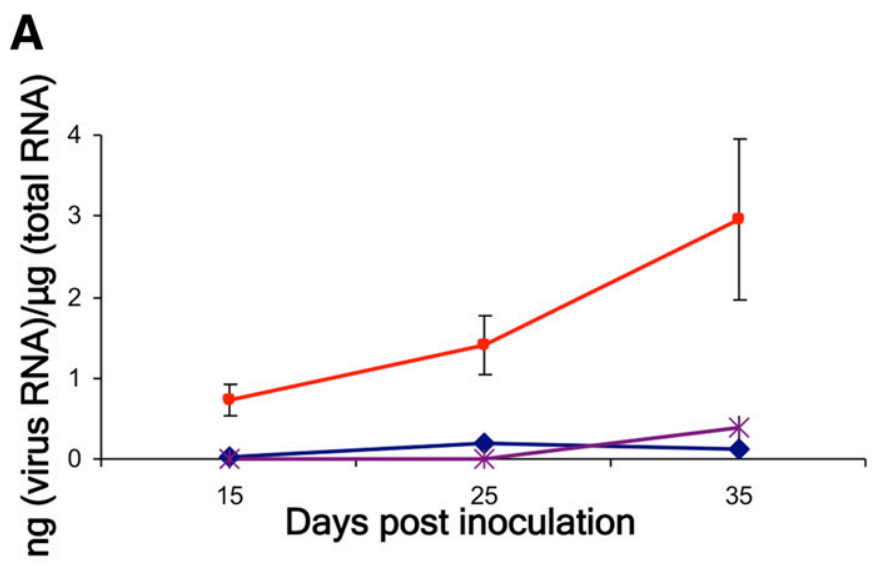

B

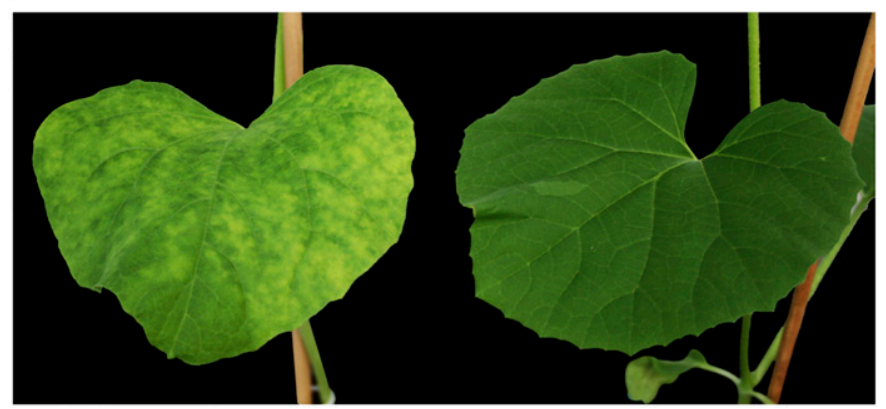

Fig. 3. Systemic accumulation of Cucurbit aphid-borne yellows virus (CABYV) in susceptible and resistant melon accessions. A, Accumulation of CABYV RNA in 'Bola de Oro' (B.ORO, susceptible), TGR-1551 (resistant) and PI 124112 (resistant) systemically infected plant leaves at 15, 25, and 35 days postinoculation by using real-time quantitative polymerase chain reaction. Each point corresponds to the average viral RNA accumulation in 10 plants after analyzing all the leaves above the cotyledons. B, First leaves above cotyledons of 'Bola de Oro' (left side) and TGR-1551 (right side) at 25 days post-CABYV agroinoculation. TGR-1551 shows no symptoms while the 'Bola de Oro' leaf displays evident yellowing symptoms. 
using quantitative dot-blots on samples from homogenates of all leaves from each plant at 15 dpi. All 'Bola de Oro' plants showed evident yellowing symptoms at $15 \mathrm{dpi}$, with the average viral RNA accumulation in this cultivar being $4.37 \pm 1.71 \mathrm{ng}$ of viral RNA/ $\mu \mathrm{g}$ of total RNA; these plants were scored as susceptible. TGR-1551 plants showed a response similar to the resistant control PI 124112 plants in which no symptoms were observed, and their average viral RNA titer was $0.96 \pm 0.28$ and $0.24 \pm 0.06 \mathrm{ng}$ of viral RNA/ $\mu \mathrm{g}$ of total RNA, respectively; these plants were scored as resistant. $\mathrm{F}_{1}$ plants showed a behavior similar to TGR-1551, with viral RNA concentration averaging $1.06 \pm 0.12 \mathrm{ng}$ of viral $\mathrm{RNA} / \mu \mathrm{g}$ of total RNA, suggesting the importance of dominant factors in the control of CABYV resistance in TGR-1551. All the $\mathrm{BC}_{1 \mathrm{R}}$ were scored as resistant and $\mathrm{F}_{2}$ and $\mathrm{BC}_{1 \mathrm{~S}}$ plants showed segregation for resistance. For the simplest model considered, one dominant gene controls the resistance in TGR-1551 (Table 1); however, the $\mathrm{BC}_{1 \mathrm{~S}}$ segregation did not fit the expected 1:1 ratio since more resistant plants than expected were observed. This result could be explained by assuming that there are genetic factors in 'Bola de Oro' contributing to the resistance.

A quantitative data analysis by Joint Scaling tests fits with a genetic model where the dominant component is the most important one (mdhil). In that model, with a maximum likelihood $\left(\chi^{2}=5.45 \mathrm{E}-\right.$ $05, P=0.99)$, epistatic additive $\times$ additive $(i)$, and dominance $\times$ dominance $(l)$ effects are also involved. Thus, there appears to be at least three genes controlling TGR-1551 resistance to CABYV $\left(n_{e}=\right.$ $3.303 \pm 0.306)$.

Both treatments of the data, qualitative and quantitative, lead to similar results, strongly suggesting that the resistance to CABYV in TGR-1551 is controlled by one dominant gene and at least two additional genetic factors involved in modifying the character; one of these genetic factors seems to be present in 'Bola de Oro'.

Aphid inoculation of CABYV to and from TGR-1551 plants. We designed a set of experiments to elucidate if CABYV, a persistently transmitted virus, can be transmitted to and from TGR-1551 plants by A. gossypii in spite of the presence of the Vat gene. Our transmission assays indicated that the transmission rate of CABYV to 'Primal' plants (mean $=51.9 \%$ ) was significantly higher $(P<0.05)$ than that to TGR-1551 plants $($ mean $=2.5 \%)$ in two replicates of the experiment (assays 1 and 2) (Table 2). The percentage of aphids that were under the phloem salivation phase (waveform E1) in both Primal and TGR-1551 plants during the first $30 \mathrm{~h}$ of recording is shown in Figure 4A. The results indicated that some aphids were able to salivate in the phloem sieve elements in both melon genotypes, with a higher percentage of aphids salivating on TGR-1551 than on Primal. However, aphids accepted Primal plants much better as a feeding source as revealed by the higher percentage of aphids that remained under the phloem ingestion phase in Primal than in TGR-1551 melon plants (Fig. 4B). The mean number of phloem salivation phases (E1) per aphid was significantly higher on TGR-1551 than on Primal $(17.00 \pm 5.11$ versus $3.45 \pm 0.91$, respectively; $P=0.012$ ) (Fig. $5 \mathrm{~A}$, bars on the

TABLE 1. Segregation of the character Cucurbit aphid-borne yellows virus accumulation in progeny of the cross between TGR-1551 and 'Bola de Oro'

\begin{tabular}{lcccc}
\hline Progeny & $\begin{array}{c}\text { Observed } \\
\text { segregation }(\mathrm{R}: \mathrm{S})^{\mathrm{a}}\end{array}$ & $\begin{array}{c}\text { Expected } \\
\text { ratio }(\mathrm{R}: \mathrm{S})^{\mathrm{a}}\end{array}$ & $\chi^{2}$ value & $P$ \\
\hline 'Bola de Oro' & $0: 10$ & $0: 1$ & & \\
TGR-1551 & $7: 0$ & $1: 0$ & & \\
$\mathrm{~F}_{1}$ & $10: 0$ & $1: 0$ & & \\
$\mathrm{~F}_{2}$ & $168: 72$ & $3: 1$ & 3.2 & 0.0736 \\
$\mathrm{BC}_{1 \mathrm{~S}}\left(\mathrm{~F}_{1} \times\right.$ & & & & \\
'Bola de Oro') & $57: 12$ & $1: 1$ & 29.35 & $6 \mathrm{E}-08$ \\
$\mathrm{BC}_{1 \mathrm{R}}\left(\mathrm{F}_{1} \times\right.$ & $44: 0$ & $1: 0$ & & \\
$\quad$ TGR-1551) & & & \\
\hline
\end{tabular}

${ }^{a} \mathrm{R}$, resistant plants (virus accumulation at 15 days postinoculation (dpi) $<2.3 \mathrm{ng}$ of viral RNA/ $\mu \mathrm{g}$ of total RNA). S, susceptible plants (virus accumulation at $15 \mathrm{dpi} \geq 2.3 \mathrm{ng}$ of viral RNA/ $\mu$ g of total RNA). left); furthermore, aphids showed a longer mean phloem salivation period on TGR-1551 $(4.06 \pm 1.39 \mathrm{~h})$ than on the susceptible Primal melon plants $(0.49 \pm 0.17 \mathrm{~h})$ (Fig. $5 \mathrm{~B}$, bars on the left). These results show that aphids actually stay longer in the phloem salivation phase in TGR-1551 plants, an activity that is known to be linked to the inoculation of luteoviruses (Prado and Tjallingii 1994). In experiments to test the acquisition of CABYV from TGR-1551 source plants, we found that aphids were able to acquire the virus from resistant TGR-1551 plants at a similar rate $(8 / 22,36.4 \%)$ than those feeding on 'Primal' source plants (60 and $43.8 \%$, Table 2). This result is consistent with those of the feeding behavior studies (Figs. 4B and 5) where aphids showed phloem ingestion activity (E2) in both genotypes from the beginning of the sixth hour of recording. However, the mean number of E2 phases per aphid was significantly $(P=0.012)$ higher on TGR-1551 $(10.00 \pm 3.03)$ than on Primal $(2.78 \pm$ 0.68) (Fig. 5A, bars on the right) but the mean duration of the E2 phase was significantly $(P=0.002)$ higher on susceptible Primal $(40.83 \pm 2.53 \mathrm{~h})$ than on TGR-1551 $(16.30 \pm 5.80 \mathrm{~h})$ melon plants (Fig. 5B, bars on the right). Therefore, viruliferous aphids can salivate and feed from the phloem of TGR-1551 plants. These and the above results strongly suggest that the observed reduction in virus transmission efficiency is not related with reduced salivation by $A$. gossypii in phloem sieve elements but due to impairment of virus accumulation or translocation after it reaches the phloem sieve elements.

\section{DISCUSSION}

TGR-1551 is resistant to several melon pests, including the viruses CYSDV (López-Sesé and Gómez-Guillamón 2000; Marco et al. 2003) and WMV (Díaz-Pendón et al. 2005; González-Ibeas et al. 2012; Palomares-Rius et al. 2011). In this paper we describe results indicating that TGR-1551 is also resistant to CABYV. Our data showed that accumulation of CABYV in agroinoculated TGR1551 cotyledons was similar to that in fully susceptible controls, but the systemic accumulation of the virus was significantly reduced in TGR-1551 plants compared with control plants. Thus, it is possible that the TGR-1551 resistance to CABYV is due to restricted movement of the virus in the vascular system of the plants, as has been shown to be the case for several other host/virus incompatible interactions (reviewed in Gómez et al. 2009). Alternatively, it may be that a resistance response is initiated after local viral multiplication such that the virus accumulates systemically to low levels; in this case, an inducible mechanism could exist in the resistant tissue that prevents high levels of virus accumulation.

Our genetic analysis indicated that resistance to CABYV in TGR1551 is controlled by one major gene, although two more genetic factors are likely involved and explain the unacceptable fit to the expected 1:1 resistant/susceptible ratio in the $\mathrm{BC}_{1 \mathrm{~S}}$. Based on our quantitative analysis, there are at least three genes responsible for the resistance to the virus. It is worth considering whether the same genetics may underlie TGR-1551 resistances to CABYV, WMV,

TABLE 2. Transmission efficiency of Cucurbit aphid-borne yellows virus (CABYV) by Aphis gossypii from 'Primal'-infected source plants to susceptible (Primal) and resistant (TGR-1551) melon test plants ${ }^{\mathrm{a}}$

\begin{tabular}{lccc}
\hline & \multicolumn{2}{c}{$\%$ Transmission } & \\
\cline { 2 - 3 } & 'Primal' & TGR-1551 & $P$ value \\
\hline Assay 1 & $60.0(6 / 10)$ & $0.0(0 / 20)$ & 0.0004 \\
Assay 2 & $43.8(7 / 16)$ & $5.0(1 / 20)$ & 0.0121 \\
\hline a Aphids were subjected to an acquisition access period of $48 \mathrm{~h}$ on a CABYV- \\
infected 'Primal' source plant and an inoculation access period of $72 \mathrm{~h}$ on \\
either 'Primal' or TGR-1551 receptor plants. \\
b Percentage of infected plants. Number of plants infected per total number of \\
plants tested is in parentheses. Significant differences $(P \leq 0.05)$ according to \\
a Fisher exact test.
\end{tabular}

Vol. 105, No. 10, 2015 

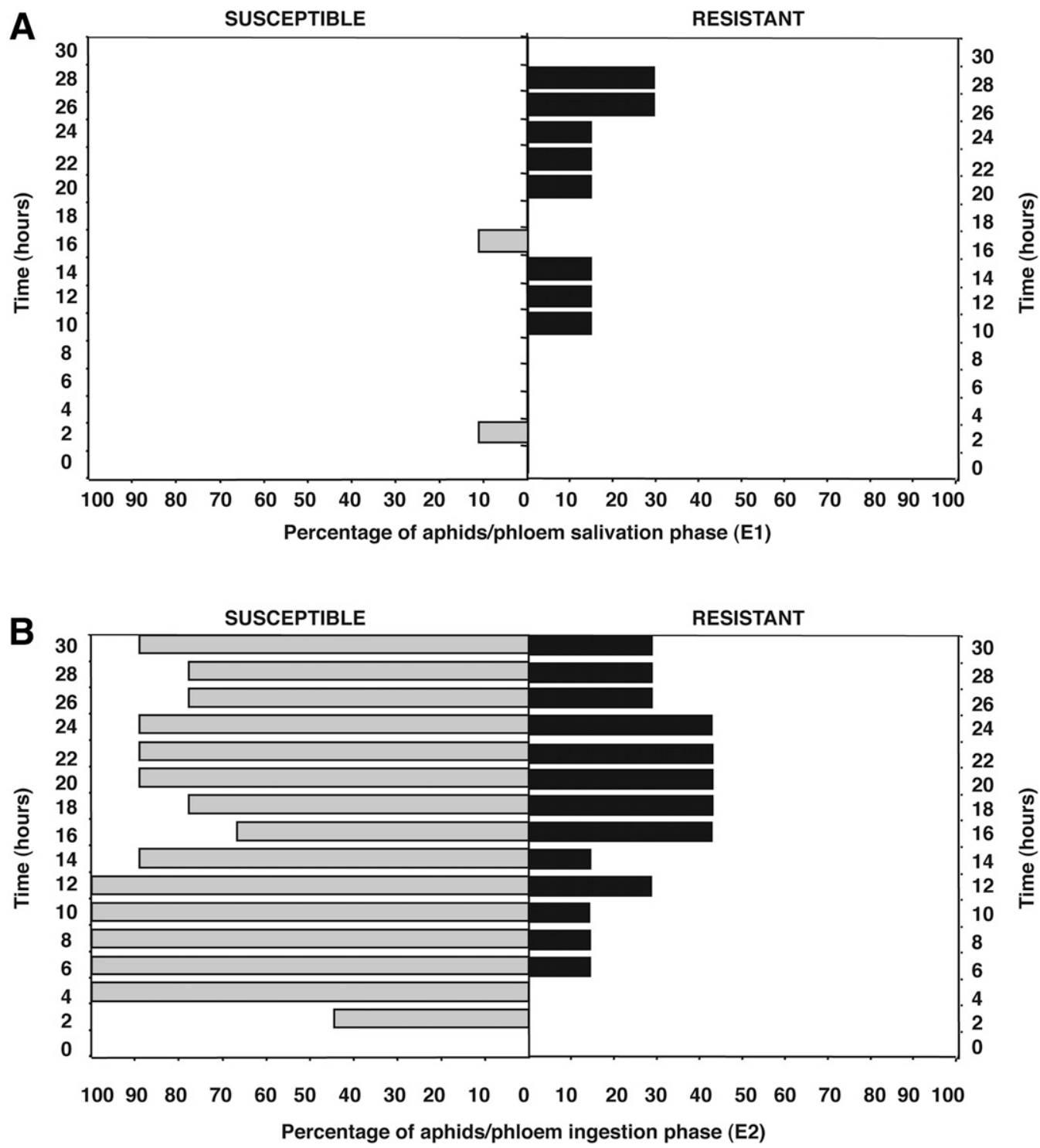

Fig. 4. Percentage of aphids/phloem activity feeding on susceptible (Primal) and resistant (TGR-1551) melon plants during $30 \mathrm{~h}$ of recording. A, Phloem salivation activity (E1). B, Phloem ingestion activity (E2) $(n=13$ for each genotype).

Number of phloem feeding activities

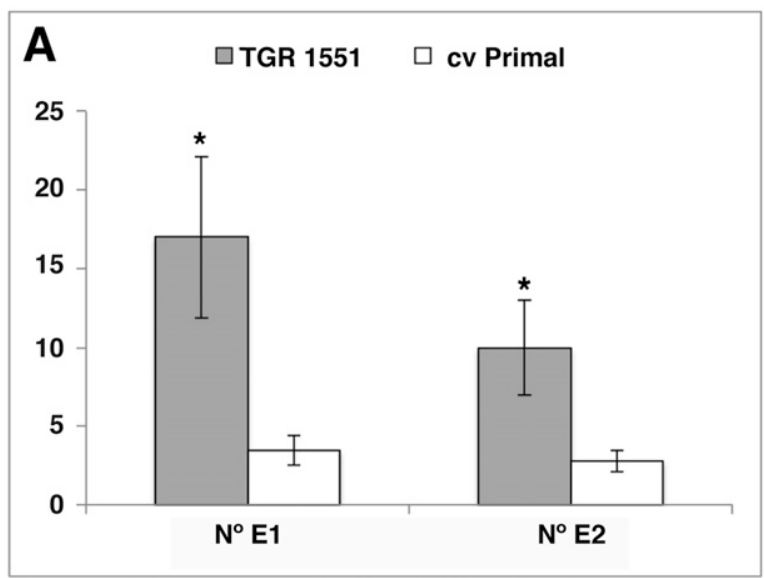

Total duration of phloem feeding activities

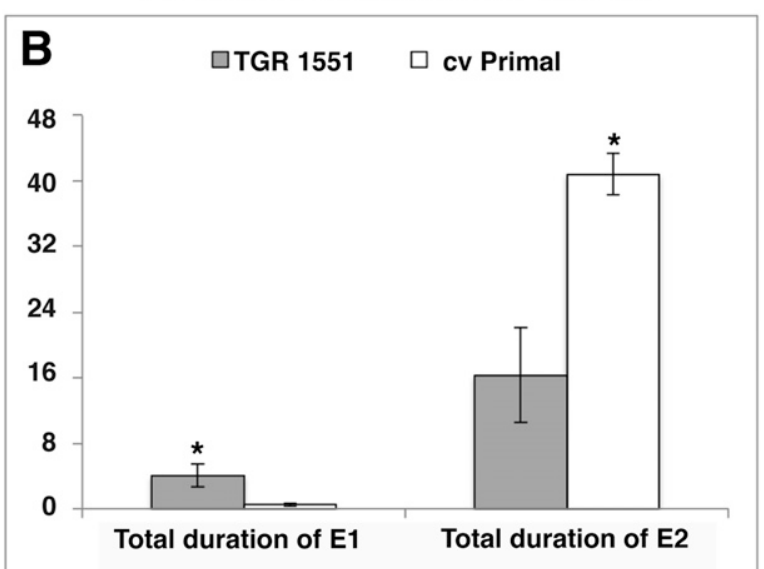

Fig. 5. Electrical penetration graph (EPG) parameters (means \pm SE) of Aphis gossypii feeding on resistant (TGR-1551) and susceptible (Primal) melon plants during $48 \mathrm{~h}$ inoculation access period. A, Number of waveforms per aphid. B, Total duration of waveform per aphid. E1, salivation into the sieve elements (bars on the left); E2, passive sap uptake from phloem sieve elements (bars on the right). Time in hours.* indicates significant differences according to a Mann-Whitney $U$ test. 
and CYSDV. This seems to be an unlikely hypothesis for CABYV and WMV as, in spite of similarities on the resistance expression phenotypes (this work and González-Ibeas et al. 2012), resistance is clearly recessive for WMV (Díaz-Pendón et al. 2005). For CABYV and CYSDV resistances, phenotypes of resistance expression are also somehow similar, with TGR-1551 plants allowing systemic replication and accumulation of both viruses albeit to significantly reduced levels (this work and Marco et al. 2003). Moreover, both viruses are phloem-limited; therefore, shared genetics for both resistance events seems a likely possibility that should be considered for further research. In contrast, what is clear is that different genes control CABYV resistance in TGR-1551 and PI 124112 plants. Thus, an $\mathrm{F}_{2}$ obtained from the cross between TGR-1551 and PI 124112 was also agroinoculated and some plants showed susceptibility to CABYV; although the behavior of the $F_{1}$ coming from the cross between TGR-1551 and 'Bola de Oro' already pointed out to the existence of different genetic control in PI 124112 and TGR-1551. Also, the identification of susceptible genotypes in that $F_{2}$ confirmed that resistance in both genotypes is conferred by different genes, although some genetic factors associated with the resistance of TGR-1551 should be present since more resistant plants than expected have been observed. Dogimont et al. (1997) described that two complementary recessive genes control the resistance in PI 124112. The segregation observed in that $F_{2}$ then suggested that one of the recessive genes present in PI 124112 could also be present in TGR-1551.

The above-discussed data were obtained after CABYV inoculation using an agroinfectious clone; thus, it seemed important to revisit these results using vector inoculations. Our EPG studies revealed that CABYV-viruliferous aphids had long salivation periods (E1) on TGR-1551 plants during the $48 \mathrm{~h}$ IAP. This would suggest that aphids could be effective transmitters of CABYV, as phloem salivation is linked to the inoculation of BYDV (Prado and Tjallingii 1994), another phloem-restricted virus that belongs to the same family (Luteoviridae). However, the transmission experiments showed that TGR-1551 had a high resistance to infection by CABYV when viruliferous aphids were subjected to a $48 \mathrm{~h}$ IAP on test plants. Very long periods of E1 salivation following sieve element penetration, and frequent stylet withdrawing from the sieve elements without engaging in phloem sap ingestion are indicative of phloem protein occlusion of sieve elements that induces resistance to aphid feeding (Alvarez et al. 2007; Garzo et al. 2002; Klingler et al. 1998; Medina-Ortega and G. Walker 2014; Sauge et al. 1998; Tjallingii 2006). Bencharki et al. (2010) suggested that phloem proteins might have an effect on the systemic movement of viruses within the plant and could also play a role in resistance to virus transmission by aphids. Also, trafficking through plasmodesmata could be facilitated by certain phloem sap proteins, which have been reported to modify the size-exclusion limit of the plasmodesmata connecting adjacent cells (Balachandran et al. 1997; Ishiwatari et al. 1998). In addition, Sarria et al. 2009b suggested that the resistance conferred by Vat gene in TGR-1551 was associated with a hypersensitive response-damage to the plasmalemma and a micro-oxidative burst of plant cells. This reaction was triggered specifically by A. gossypii after epidermal or mesophyll cell punctures. Such aphidspecific plant reaction confers resistance to the transmission of a nonpersistent virus such as Cucumbermosaic virus (CMV) to plants carrying the Vat gene when A. gossypii is used as a vector (Lecoq et al. 1979). A similar hypersensitive response may interfere with virus movement when A. gossypii punctures phloem sieve elements and inoculates CABYV to TGR-1551 plants. Therefore, restriction of CABYV movement seems to be the most convincing explanation for the very low CABYV-transmission rate observed on TGR-1551 plants. Other possibilities such as differences in the feeding behavior between viruliferous and nonviruliferous aphids are less likely. In fact, the work conducted by Garzo et al. (2002) using nonviruliferous aphids showed a similar phloem feeding behavior as those reported in the present work with viruliferous aphids consisting of long salivation periods (E1) and shorter ingestion periods (E2) on TGR-1551 plants. Our results also show that the acquisition rate of CABYV from TGR-1551 or from Primal was rather similar. This observation is in agreement with the shorter phloem ingestion periods observed on TGR-1551 (16.30 $\pm 5.80 \mathrm{~h})$ compared with those on Primal $(40.83 \pm 2.53 \mathrm{~h})$ plants. Lecoq et al. (1979) observed similar effects in plants of the melon line PI 161375 that carries the Vat gene. Their results indicated that PI 161375 was resistant to inoculation but susceptible to the acquisition of a nonpersistent virus such as CMV by $A$. gossypii. Therefore, we could conclude that the observed probing behavior of the vector cannot explain the resistance mechanism, and that other reasons, including the impairment of virus movement or translocation though the phloem sieve elements may interfere in the infection process, in agreement with data obtained using agroinoculations.

Introgression into commercial cultivars of the resistance to CABYV that we have characterized would be particularly interesting due to the relevance of CABYV-induced diseases. The single gene model together with at least two more genetic factors appears to be valid for use in a backcross breeding scheme to transfer resistance to different melon lines; also, although it should be confirmed in other cultivars, the presence of genetic factors in the susceptible cultivar affecting the resistance would make obtaining resistant cultivars with different fruit types easier. The success in such a breeding program would also be strengthened by the fact that TGR-1551 shows resistance to A. gossypii, since it carries the Vat gene (Sarria et al. 2009 b), and this aphid is the most important one affecting melon crops.

\section{ACKNOWLEDGMENTS}

This work was supported by grants 11934/PI/09 (Fundación Séneca de la Región de Murcia, Spain), and AGL2012-37390 and AGL2011-29516C02-02 (Ministerio de Economía y Competitividad, Spain). We thank M. C. Montesinos and B. Gosalvez for their excellent technical assistance, and W. F. Tjallingii for expert help. M. Fon (mariogfon@gmail.com) checked the English.

\section{LITERATURE CITED}

Alvarez, A. E., Garzo, E., Verbeek, M., Dicke, M., Vosman, B., and Tjallingii, W. F. 2007. Infection of potato plants with Potato leafroll virus changes attraction and feeding behaviour of Myzus persicae. Entomol. Exp. Appl. 125:135-144.

Ashoub, A., Rohde, W., and Prüfer, D. 1998. In planta transcription of a second subgenomic RNA increase the complexity of the subgroup 2 luteovirus genome. Nucleic Acids Res. 26:420-426.

Balachandran, S., Xiang, Y., Schobert, C., Thompson, G. A., and Lucas, W. J. 1997. Phloem sap proteins from Cucurbita maxima and Ricinus communis have the capacity to traffic cell to cell through plasmodesmata. Proc. Natl. Acad. Sci. USA 94:14150-14155.

Bananej, K., Vahdat, A., Predajna, L., and Glasa, M. 2009. Molecular characterization of geographically different Cucurbit aphid-borne yellows virus isolates. Acta Virol. 53:61-64.

Bencharki, B., Boissinot, S., Revollon, S., Ziegler-Graff, V., Erdinger, M., Wiss, L., Dinant, S., Renard, D., Beuve, M., Lemaitre-Guillier, C., and Brault, V. 2010. Phloem protein partners of Cucurbit aphid borne yellows virus: Possible involvement of phloem proteins in virus transmission by aphids. Mol. Plant-Microbe Interact. 23:799-810.

Bjarko, M. E., and Line, R. F. 1988. Quantitative determination of the gene action of leaf rust resistance on four cultivars of wheat, Triticum aestivum. Phytopathology 78:451-456.

Boissinot, S., Erdinger, M., Monsion, B., Ziegler-Graff, V., and Brault, V. 2014. Both structural and non-structural forms of the readthrough protein of Cucurbit aphid-borne yellows virus are essential for efficient systemic infection of plants. PLoS One 9:e93448.

Brault, V., Périgon, S., Reinbold, C., Erdinger, M., Scheidecker, D., Herrbach, E., Richards, K., and Zielgler-Graff, V. 2005. The Polerovirus minor capsid protein determines vector specificity and intestinal tropism in the aphid. J. Virol. 79:9685-9693.

Brault, V., van den Heuvel, J. F. J. M., Verbeek, M., Ziegler-Graff, V., Reutenauer, A., Herrbach, E., Garaud, J. C., Guilley, H., Richards, K., and Jonard, G. 1995. Aphid transmission of beet western yellows 
luteovirus requires the minor capsid read-through protein P74. EMBO J. 14:650-659.

D'Arcy, C. J., and Domier, L. L. 2005. Luteoviridae. In: Virus Taxonomy: VIIIth Report of the International Committee on Taxonomy of Viruses. M. A. Mayo, J. Maniloff, U. Desselberger, L. A. Ball, and C. M. Fauquet, eds. Academic Press, New York.

Díaz-Pendón, J. A., Fernández-Muñoz, R., Gómez-Guillamón, M. L., and Moriones, E. 2005. Inheritance of resistance to Watermelon mosaic virus in Cucumis melo that impairs virus accumulation, symptom expression, and aphid transmission. Phytopathology 95:840-846.

Dogimont, C., Bussemakers, A., Martin, J., Slama, S., Lecoq, H., and Pitrat, M. 1997. Two complementary recessive genes conferring resistance to cucurbit aphid borne yellows luteovirus in an Indian melon line (Cucumis melo L.). Euphytica 96:391-395.

Dogimont, C., Slama, S., Martin, J., Lecoq, H., and Pitrat, M. 1996. Sources of resistance to cucurbit aphid-borne yellows luteovirus in a melon germ plasm collection. Plant Dis. 80:1379-1382.

Garzo, E., Soria, C., Gómez-Guillamón, M. L., and Fereres, A. 2002. Feeding behavior of Aphis gossypii on resistant accessions of different melon genotypes (Cucumis melo). Phytoparasitica 30:129-140.

Gildow, F. E., Reavy, B., Mayo, M. A., Duncan, G. H., Woodford, J. A. T., Lamb, J. W., and Hay, R. T. 2000. Aphid acquisition and cellular transport of potato leafroll virus-like particles lacking P5 readthrough protein. Phytopathology 90:1153-1161.

Gómez, P., Sempere, R. N., Elena, S. F., and Aranda, M. A. 2009. Mixed infections of Pepino mosaic virus strains modulate the evolutionary dynamics of this emergent virus. J. Virol. 83:12378-12387.

González-Ibeas, D., Cañizares, J., and Aranda, M. A. 2012. Microarray analysis shows that recessive resistance to Watermelon mosaic virus in melon is associated with the induction of defense response genes. Mol. Plant-Microbe Interact. 25:107-118.

Guilley, H., Wipf-Scheibel, C., Richards, K., Lecoq, H., and Jonard, G. 1994. Nucleotide sequence of cucurbit aphid-borne yellows luteovirus. Virology 202:1012-1017.

Ishiwatari, Y., Fujiwara, T., McFarland, K. C., Nemoto, K., Hayashi, H., Chino, M., and Lucas, W. J. 1998. Rice phloem thioredoxin has the capacity to mediate its own cell-to-cell transport through plasmodesmata. Planta 205:12-22.

Juárez, M., Legua, P., Mengual, C. M., Kassem, M. A., Sempere, R. N., Gómez, P., Truniger, V., and Aranda, M. A. 2013. Relative incidence, spatial distribution and genetic diversity of cucurbit viruses in eastern Spain. Ann. Appl. Biol. 162:362-370.

Juárez, M., Truniger, V., and Aranda, M. A. 2004. First report of Cucurbit aphid-borne yellows virus in Spain. Plant Dis. 88:907.

Kassem, M. A., Juárez, M., Gómez, P., Mengual, C. M., Sempere, R. N., Plaza, M., Elena, S. F., Moreno, A., Fereres, A., and Aranda, M. A. 2013. Genetic diversity and potential vectors and reservoirs of Cucurbit aphid-borne yellows virus in southeastern Spain. Phytopathology 103:1188-1197.

Kassem, M. A., Sempere, R. N., Juárez, M., Aranda, M. A., and Truniger, V. 2007. Cucurbit aphid-borne yellows virus is prevalent in field-grown cucurbit crops of southeastern Spain. Plant Dis. 91:232-238.

Klingler, J., Powell, G., Thompson, G. A., and Isaacs, R. 1998. Phloem specific aphid resistance in Cucumis melo line AR 5: Effects on feeding behaviour and performance of Aphis gossypii. Entomol. Exp. Appl. 86: 79-88.

Knierim, D., Deng, T. C., Tsai, W. S., Green, S. K., and Kenyon, L. 2010. Molecular identification of three distinct Polerovirus species and a recombinant Cucurbit aphid-borne yellows virus strain infecting cucurbit crops in Taiwan. Plant Pathol. 59:991-1002.

Lande, R. 1981. The minimum number of genes contributing to quantitative variation between and within populations. Genetics 99:541-553.

Lecoq, H. 1999. Epidemiology of Cucurbit aphid-borne yellows virus. Pages 243-248 in: The Luteoviridae. H. G. Smith, and H. Baker, eds. CAB International, Wallingford, UK.

Lecoq, H., Bourdin, D., Wipf-Scheibel, C., Bon, M., Lot, H., Lemaire, O., and Herbach, E. 1992. A new yellowing disease of cucurbits caused by a luteovirus, cucurbit aphid-borne yellows virus. Plant Pathol. 41:749-761.

Lecoq, H., Cohen, S., Pitrat, M., and Labonne, G. 1979. Resistance to $\mathrm{Cu}$ cumber mosaic virus transmission by aphids in Cucumis melo. Phytopathology 69:1223-1225.

Lecoq, H., Dafalla, G., Desbiez, C., Wipf-Scheibel, C., and Kheyr-Pour, A. 2003. A 10-year survey (1993-2002) of cucurbit viruses in Sudan. J. Plant Dis. Prot. 110:68-69.

Lemaire, O., Gubler, W. D., Valencia, J., Lecoq, H., and Falk, B. W. 1993. First report of cucurbit aphid-borne yellows luteovirus in the Unites States. Plant Dis. 77:1169.
López-Sesé, A. I., and Gómez-Guillamón, M. L. 2000. Resistance to CYSDV in C. melo. HortScience 35:110-113.

Marco, C. F., Aguilar, J. M., Abad, J., Gómez-Guillamón, M. L., and Aranda, M. A. 2003. Melon resistance to Cucurbit yellow stunting disorder virus is characterized by reduced virus accumulation. Phytopathology 93:844-852.

Mather, K., and Jinks, R. F. 1982. Biometrical Genetics: The Study of Continuous Variation. Chapman and Hall, New York and London.

Mayo, M. A., and Ziegler-Graff, V. 1996. Molecular biology of luteoviruses. Adv. Virus Res. 46:413-460.

Medina-Ortega, K. J., and Walker, P. 2014. Faba bean forisomes can function in defense against generalist aphids. Plant, Cell \& Environ. 38:1167-1177.

Moreno, A., Garzo, E., Fernandez-Mata, G., Kassem, M., Aranda, M. A., and Fereres, A. 2011. Aphids secrete watery saliva into plant tissues from the onset of stylet penetration. Entomol. Exp. Appl. 139:145-153.

Palomares-Rius, F. J., López-Sesé, A. I., and Gómez-Guillamón, M. L. 2007. Evaluation of non-preference of melon plants by Bemisia tabaci. Cucurbit Genet. Cooperative 30:23-25.

Palomares-Rius, F. J., Viruel, M. A., Yuste-Lisbona, F. J., López-Sesé, A. I., and Gómez-Guillamón, M. L. 2011. Simple sequence repeat markers linked to QTL for resistance to Watermelon mosaic virus in melon. Theor. Appl. Genet. 123:1207-1214.

Pfeffer, S., Dunoyer, P., Heim, F., Richards, K. E., Jonard, G., and Ziegler-Graff, V. 2002. P0 of Beet western yellow virus is a suppressor of posttranscriptional gene silencing. J. Virol. 76:6815-6824.

Prado, E., and Tjallingii, W. F. 1994. Aphid activities during sieve element punctures. Entomol. Exp. Appl. 72:157-166.

Prüfer, D., Kawchuk, L. M., and Rohde, W. 2006. Polerovirus ORF0 genes induce a host-specific response resembling viral infection. Can. J. Plant Pathol. 28:302-309.

Prüfer, D., Wipf-Scheibel, C., Richards, K., Guilley, H., Lecoq, H., and Jonard, G. 1995. Synthesis of a full-length infectious cDNA clone of cucurbit aphid-borne yellows virus and its use in gene exchange experiments with structural proteins from other luteoviruses. Virology 214:150-158.

Sarria, E., Cid, M., Garzo, E., and Fereres, A. 2009a. Excel Workbook for automatic parameter calculation of EPG data. Comput. Electron. Agric. 67: $35-42$.

Sarria, E., Garzo, E., López-Sesé, A. I., Fereres, A., and Gómez-Guillamón, M. L. 2009b. Hypersensitive response to Aphis gossypii Glover in melon genotypes carrying the Vat gene. J. Exp. Bot. 60:3269-3277.

Sarria, E., López-Sesé, A. I., and Gómez-Guillamón, M. L. 2007. High density of Type I trichomes related to tolerance to Aphis gossypii in primitive melon accessions. Cucurbit Genet. Coop. 30:26-28.

Sarria, E., Palomares-Rius, F. J., López-Sesé, A. I., Heredia, A., and Gómez-Guillamón, M. L. 2010. Role of glandular leaf trichomes of melon plants in the deterrence of Aphis gossypii Glover. Plant Biol. 12:503-511.

Sauge, M. H., Kervella, J., and Rahbé, Y. 1998. Probing behaviour of the green peach aphid Myzus persicae on resistant Prunus genotypes. Entomol. Exp. Appl. 89:223-232.

Soria, C., Garzo, E., Fereres, A., Moriones, E., and Gómez-Guillamón, M. L. 2003. New source of resistance to mosaic virus transmission by Aphis gossypii in melon. Euphytica 133:313-318.

Soria, C., López-Sesé, A. I., and Gómez-Guillamón, M. L. 1999. Resistance in Cucumis melo against Bemisia tabaci Gennadius. J. Environ. Entomol. 28: 831-835.

Tjallingii, W. F. 1985. Membrane potentials as an indication for plant cell penetration by aphid stylets. Entomol. Exp. Appl. 38:187-193.

Tjallingii, W. F. 2006. Salivary secretions by aphids interacting with proteins of phloem wound responses. J. Exp. Bot. 57:739-745.

Yardimci, N., and Özgönen, H. 2007. First report of Cucurbit aphid-borne yellows virus in Turkey. Australas. Plant Dis. Notes 2:59.

Yuste-Lisbona, F. J., Capel, C., Gómez-Guillamón, M. L., Capel, J., López-Sesé, A. I., and Lozano, R. 2011a. Codominant PCR-based markers and candidate genes for powdery mildew resistance in melon (Cucumis melo L.). Theor. Appl. Genet. 122:747-758.

Yuste-Lisbona, F. J., Capel, C., Sarria, E., Torreblanca, R., Gómez-Guillamón, M. L., Capel, J., Lozano, R., and López-Sesé, A. I. 2011b. Genetic linkage map of melon (Cucumis melo L.) and localization of a major QTL for powdery mildew resistance. Mol. Breed. 27:181-192.

Yuste-Lisbona, F. J., López-Sesé, A. I., and Gómez-Guillamón, M. L. 2010. Inheritance of resistance to races 1, 2 and 5 of powdery mildew in the melon TGR-1551. Plant Breed. 129:72-75.

Ziegler-Graff, V., Brault, V., Mutterer, J. D., Simionis, M. T., Herrbach, E., Guilley, H., Richards, K. E., and Jonard, G. 1996. The coat protein of Beet western yellows Luteovirus is essential for systemic infection but the viral gene products P29 and P19 are dispensable for systemic infection and aphid transmission. Mol. Plant-Microbe Interact. 9:501-510. 